\title{
IMPLEMENTASI PERCEPATAN PEMBANGUNAN DESA DALAM MEWUJUDKAN PEMBANGUNAN BERKELANJUTAN BERDASARKAN UNDANG-UNDANG NOMOR 6 TAHUN 2014 TENTANG DESA
}

\begin{abstract}
Abustan
Program Pascasarjana Universitas Islam Jakarta

Email: cakbus.community@ gmail.com

Info Artikel:

Diterima: 20 September 2019 | Disetujui: 01 November 2019 | Dipublikasikan: 27 Desember 2019

\section{Abstrak}

Dalam perjalanan ketatanegaraan Indonesia, sistem pemerintahan desa kembali mulai diseragamkan melalui Undang-Undang Nomor 6 Tahun 2014 tentang Desa. Penelitian ini bertujuan untuk menjelaskan peran lembaga pemerintahan desa dalam pelaksanaan pembangunan berkelanjutan di pedesaan serta tata kelola kebijakan pembangunan desa melalui pemanfaatan Dana Desa. Metode yang digunakan dalam penelitian ini adalah penelitian hukum empiris. Hasil penelitian ini menjelaskan bahwa faktor pendukung pelaksanaan tugas Kepala Desa di Kecamatan Trucuk yaitu adanya pengarahan, bimbingan, serta pelatihan bagi Kepala Desa dalam menyusun rancangan peraturan desa untuk mewujudkan percepatan pembangunan desa yang berkelanjutan. Sedangkan faktor yang menghambat pelaksanaan tugas Kepala Desa di Kecamatan Trucuk yaitu rendahnya partisipasi masyarakat dalam menyikapi program kerja yang dijalankan oleh pemerintah desa serta rendahnya kesadaran masyarakat dalam memelihara fasilitas umum yang ada di desa. Pemerintahan desa yang baik adalah sebuah kerangka institusional untuk memperkuat otonomi desa karena secara substantif desentralisasi dan otonomi desa bukan hanya masalah pembagian kewenangan antarlevel pemerintah, melainkan sebagai upaya membawa pemerintah untuk lebih dekat dengan masyarakat. Pemerintah desa yang kuat dan otonom tidak akan bermakna bagi masyarakat tanpa ditopang oleh transparansi, akuntabilitas, responsivitas, dan partisipasi masyarakat.
\end{abstract}

Kata kunci: Hukum, Desa, Pembangunan Berkelanjutan

\section{IMPLEMENTATION OF ACCELERATION OF VILLAGE DEVELOPMENT IN REALIZING SUSTAINABLE DEVELOPMENT BASED ON LAW NUMBER 6 YEAR 2014 ABOUT VILLAGE Abstract}

In the course of the Indonesian state administration, the village government system began to be uniform again through Law Number 6 of 2014 concerning Villages. This research aims to explain the role of village government institutions in the implementation of sustainable development in rural areas and the governance of village development policies through the use of Village Funds. The method used in this research is empirical legal research. The results of this research explain that the supporting factors for the implementation of the duties of the village head in Trucuk Village are direction, guidance, and training for village heads in drafting village regulations to realize the acceleration of sustainable village development. Meanwhile, the factors that hinder the implementation of the duties of the village head in Trucuk Village are the low participation of the community in responding to the work programs run by the village government and the low awareness of the community in maintaining public facilities in the village. Good village governance is an institutional framework to strengthen village autonomy because substantively decentralization and village autonomy are not just a matter of sharing authority between levels of government, but as an effort to bring the government closer to the community. A strong and autonomous village government will not be meaningful to the community without being supported by transparency, accountability, responsiveness and community participation.

Keywords: Law, Village, Sustainable Development 


\section{A. PENDAHULUAN}

Indonesia adalah negara hukum, yang menjadi postulat penting yang tertuang dalam teks konstitusi Undang-Undang Dasar Negara Republik Indonesia Tahun 1945. Artinya, Indonesia berkomitmen bahwa negara hukum merupakan sebuah preposisi yang diidealisasikan hendak dicapai harus selalu diupayakan dan ditegakkan secara konsisten. Dalam konteks ini, jika dihubungkan dengan percepatan pembangunan desa, maka implementasi konsep negara hukum dalam pemerataan pembangunan desa berkelanjutan menghendaki adanya otoritas dan komitmen dari pemangku kepentingan negara.

Dalam perjalanan ketatanegaraan Indonesia, sistem pemerintahan desa kembali mulai diseragamkan melalui Undang-Undang Nomor 6 Tahun 2014 tentang Desa. Lahirnya Undang-Undang Nomor 6 Tahun 2014 tentang Desa setidaknya menghasilkan dua implikasi penting. Pertama, desa memiliki kewenangan penuh untuk membangun karena keberadaannya diakui dan diberi otonomisasi untuk memutuskan serta mengurus kebutuhan lokalnya sendiri. Kedua, desa memiliki sumber dana yang besar dan berhak mengurus dananya sendiri untuk percepatan pembangunan desa.

Jargon 'Desa Membangun' merefleksikan bahwa desa sendiri yang merencanakan dan melaksanakan pembangunannya dalam koridor kewenangan yang dimilikinya. Oleh karena itu, diperlukan berbagai langkah strategis dan/atau terobosan untuk meningkatkan pendapatan dan kesejahteraan penduduk desa. Desa seharusnya tidak hanya bergantung dari bantuan sosial, tetapi juga harus mampu berdiri sendiri karena ketika ketergantungan itu sudah terjadi, akan sangat rentan untuk jatuh ke jurang kemiskinan apabila penyaluran aneka bantuan tersebut mengalami penyimpangan (manipulasi). Faktor-faktor krusial ini, haruslah diantisipasi secara dini dan cepat dari perangkat pemerintahan yang ada di desa.

Selain itu, gagasan lain yang perlu dipikirkan adalah memindahkan sentra industri ke pedesaan untuk menyerap tenaga kerja dan sekaligus menggerakkan roda perekonomian desa. Pengalihan ini selain mendekatkan dengan sumber-sumber bahan baku dan tenaga kerja, juga sebagai bagian dari percepatan pembangunan desa dalam rangka memotivasi dan memacu terwujudnya pembangunan berkelanjutan. Bahkan, saat ini pemerintah melalui Kementerian Desa, Pembangunan Daerah Tertinggal, dan Transmigrasi telah meluncurkan Produk Kawasan Unggulan Pedesaan (Prukades) untuk meningkatkan nilai jual komoditas unggulan. Hal itu perlu digarisbawahi dan dikedepankan di tengah 
berbagai perkembangan dan perubahan yang terjadi yang melanda seluruh wilayah Indonesia, termasuk daerah pelosok (desa). Ke semuanya itu menunjukkan bahwa betapa pentingnya pemerintahan desa mendesain program kerja yang lebih aktual, kontekstual, dan operasional sebagai kebutuhan kekinian dalam rangka meningkatkan kualitas manusia sebagai wujud implementasi pembangunan sumber daya manusia yang ada di daerah, khususnya kehidupan masyarakat yang ada di desa.

Oleh karena itu, kesempatan untuk melakukan lompatan percepatan pembangunan dalam rangka merealisasikan kesejahteraan masyarakat desa menjadi sebuah keniscayaan. Momentum ini ditandai pula dengan kehadiran berbagai regulasi baru yang mendorong adanya dinamika kehidupan masyarakat di desa melalui amanat Undang-Undang Nomor 6 Tahun 2014 tentang Desa. Jadi, secara filosofis dan secara sosiologis, semangat pemikiran Undang-Undang Nomor 6 Tahun 2014 tentang Desa mengindikasikan bahwa desa merupakan kesatuan hukum otonomi serta memiliki hak dan wewenang untuk mengatur rumah tangganya sendiri.

Dalam Undang-Undang Nomor 23 Tahun 2014 tentang Pemerintahan Daerah, pemerintahan desa bukan merupakan level administrasi yang menjadi bawahan pemerintah daerah, melainkan menjadi independent

community

yang

masyarakatnya berhak mengambil inisiatif untuk mengembangkan desanya. Di samping itu, pelaksanaan tugas dari kepala desa dan perangkat desa lainnya juga menjadi variabel penting dari keberhasilan pembangunan desa. Kepatuhan dan ketaatan masyarakat dalam merespon perubahan sosial yang ada tentunya merupakan modal sosial yang sangat berharga, seperti yang dikemukakan oleh Satjipto Rahardjo bahwa ketaatan merupakan variabel penting, ketaatan hukum didasarkan kepada kepuasan yang diperoleh dengan dukungan sosial. ${ }^{1}$

Kepatuhan dan ketaatan hukum dapat dilacak melalui pelaksanaan tugas Kepala Desa dalam memimpin penyelenggaraan pemerintahan, seperti membuat rencana anggaran, administrasi desa, serta tata kelola pemerintahan yang bersih. Dengan demikian, langkah-langkah yang harus dilakukan dalam mengatasi permasalahan tugas Kepala Desa antara lain perlu segera disosialisasikan mengenai implementasi Undang-Undang Nomor 6 Tahun 2014 tentang Desa agar tugas maupun kewajibankewajiban seorang Kepala Desa dapat dijalankan dengan maksimal sesuai dengan mekanisme penyelenggaraan dan pertanggungjawaban dalam pembangunan desa untuk mewujudkan masyarakat yang

\footnotetext{
${ }^{1}$ Satjipto Rahardjo, Hukum dan Perubahan Sosial, (Bandung: Angkasa, 1988), hlm. 10.
} 
sejahtera. Hakikat dari pemerintah adalah melayani kepentingan masyarakat. ${ }^{2}$

Dalam rangka mengukur efektivitas pelaksanaan Undang-Undang Nomor 6 Tahun 2014 tentang Desa menggunakan teori dari Lawrence M. Friedman, perlu dilihat tiga aspek, yaitu struktur hukum, substansi hukum, dan budaya hukum. Struktur hukum adalah hal-hal yang menyangkut kelembagaan pemerintahan desa yang terkait dengan pembentukan hukum, pelaksanaan hukum, dan penegakan hukum. Substansi hukum adalah peraturanperaturan yang mengatur masyarakat desa. Sedangkan, budaya hukum adalah suatu sistem hukum yang telah ada dalam kehidupan masyarakat desa.

Bertolak dari asumsi dasar tersebut, maka diharapkan implementasi UndangUndang Nomor 6 Tahun 2014 tentang Desa dapat memacu percepatan pembangunan desa. Untuk itu, sangat diharapkan berbagai political will dari pemerintah pusat maupun pemerintah daerah untuk mendorong keberlanjutan pembangunan desa. Dengan demikian, kesejahteraan masyarakat desa sebagai manivestasi dari percepatan pembangunan dapat terlaksana dalam rangka mewujudkan pembangunan berkelanjutan.

\footnotetext{
2 Mohammad Nur Aris, Implementasi UndangUndang Nomor 6 Tahun 2014 tentang Desa, (Jakarta: Tesis Universitas Islam Jakarta, 2019), hlm. 23.
}

Dari latar belakang permasalahan yang telah diuraikan di atas, adapun rumusan masalah yang dibahas dalam penelitian ini adalah sebagai berikut: Bagaimana peran lembaga pemerintahan desa dalam pelaksanaan pembangunan berkelanjutan di pedesaan?; Bagaimana tata kelola kebijakan pembangunan desa melalui pemanfaatan Dana Desa?

\section{B. METODE PENELITIAN}

Dalam penelitian non doktrinal, hukum dimaknai sebagai manifestasi dari maknamakna simbolik perilaku sosial sebagai dampak dalam interaksi antarmasyarakat. Metode yuridis normatif mengacu pada norma-norma hukum yang terdapat dalam peraturan perundang-undangan dan putusan pengadilan serta norma-norma yang ada dalam masyarakat. ${ }^{3}$ Penelitian ini termasuk dalam tipe penelitian empiris, yaitu penelitian tentang hukum dalam pelaksanaannya, namun pada dasarnya penelitian ini tidak sepenuhnya bersifat normatif mengingat kasus-kasus yang dibahas dalam penelitian ini terjadi pada lingkup yang sebenarnya. Penelitian ini bersifat deskriptif analitis dengan menggambarkan peraturan perundangundangan yang berlaku yaitu UndangUndang Nomor 6 Tahun 2014 tentang Desa dan dikaitkan dengan teori-teori hukum.

\footnotetext{
3 Sri Mamudji, dkk., Metode Penelitian dan Penulisan Hukum, (Jakarta: Badan Penerbit Fakultas Hukum Universitas Indonesia, 2005), hlm. 14.
} 


\section{HASIL DAN PEMBAHASAN}

Desa merupakan sistem tatanan yang terendah dalam bingkai Negara Kesatuan Republik Indonesia. Realitanya, masih banyak desa di Indonesia yang keadaannya sangat memprihatinkan sehingga masuk dalam kategori desa yang tertinggal, khususnya dalam hal infrastruktur desa. Untuk menjadikan desa yang adil, makmur, dan sejahtera, maka Undang-Undang Nomor 6 Tahun 2014 tentang Desa merupakan jawabannya. Lahirnya UndangUndang Nomor 6 Tahun 2014 tentang Desa dapat meningkatkan pembangunan desa melalui anggaran yang dikucurkan oleh pemerintah pusat, yaitu Dana Desa.

Dalam Peraturan Pemerintah Nomor 76 Tahun 2001 tentang Pedoman Umum Pengaturan Desa menjelaskan bahwa desa adalah kesatuan masyarakat hukum yang memiliki kewenangan untuk mengatur dan mengurus kepentingan masyarakatnya berdasarkan asal-usul dan adat istiadat setempat yang diakui dalam sistem pemerintahan nasional. Sejalan dengan itu, dalam Undang-Undang Nomor 6 Tahun 2014 tentang Desa dijelaskan bahwa desa atau yang disebut dengan nama lain mempunyai karakteristik yang berlaku umum untuk seluruh Indonesia, sedangkan desa adat atau yang disebut dengan nama lain mempunyai karakteristik yang berbeda dari desa pada umumnya, terutama karena kuatnya pengaruh adat terhadap sistem pemerintahan lokal, pengelolaan sumber daya lokal, dan kehidupan sosial budaya masyarakatnya.

Dengan demikian, desa harus dipahami sebagai kesatuan masyarakat hukum yang memiliki kekuasaan dalam mengatur dan mengurus kepentingan masyarakatnya untuk mencapai kesejahteraan. Hak untuk mengatur dan mengurus kepentingan masyarakat inilah yang disebut Otonomi Desa. ${ }^{4}$

Desa yang diatur dalam UndangUndang Nomor 2 Tahun 1999 tentang Pemerintahan Daerah merupakan transisi dari desa seragam yang diciptakan melalui Undang-Undang Nomor 5 Tahun 1979 tentang Pemerintahan Desa. Lahirnya Undang-Undang Nomor 6 Tahun 2014 tentang Desa sekaligus memberikan landasan yang kuat bagi terwujudnya development community sehingga desa tidak lagi merupakan level administrasi pemerintah daerah, tetapi justru sebaliknya, desa merupakan independent community, sehingga pemerintah dan masyarakat desa berhak berbicara atas kepentingan desanya sendiri.

Berbeda dengan desa, desa adat pada prinsipnya merupakan warisan organisasi kepemerintahan masyarakat lokal yang dipelihara secara turun-temurun yang tetap diakui dan diperjuangkan oleh pemimpin

\footnotetext{
${ }^{4}$ Haw Widjaja, Penyelenggaraan Otonomi Daerah di Desa, (Jakarta: Rajawali Pers, 2010), hlm. 92.
} 
maupun masyarakat desa adat tersebut agar dapat berfungsi mewujudkan kesejahteraan dan mengembangkan identitas sosial kebudayaan lokal. Desa adat memiliki hak asal-usul yang lebih dominan dari pada desa pada umumnya sejak desa adat lahir sebagai komunitas asli yang ada di tengah masyarakat. Desa adat didefinisikan sebagai sebuah kesatuan masyarakat hukum adat yang secara historis mempunyai batas wilayah dan identitas budaya yang terbentuk atas dasar teritorial yang berwenang mengatur dan mengurus kepentingan masyarakatnya berdasarkan hak asal-usul. Pada dasarnya, kesatuan masyarakat hukum adat terbentuk berdasarkan tiga prinsip dasar, yaitu prinsip genealogis, prinsip teritorial, atau gabungan dari prinsip genealogis dan prinsip teritorial. Desa adat yang diatur dalam Undang-Undang Nomor 6 Tahun 2014 tentang Desa adalah kesatuan masyarakat hukum adat yang merupakan gabungan dari prinsip genealogis dan prinsip teritorial.

Oleh karena itu, negara mengakui dan menghormati kesatuan masyarakat hukum adat beserta hak tradisionalnya sepanjang masih hidup serta sesuai dengan perkembangan masyarakat dan prisnsip Negara Kesatuan Republik Indonesia. Implementasi dari kesatuan masyarakat hukum adat tersebut telah ada dan hidup di wilayah Negara Kesatuan Republik Indonesia, seperti huta/nagori di Sumetera
Utara, gamping di Aceh, nagari di Minangkabau, marga di Sumatera bagian selatan, tiuh/pekon di Lampung, desa pakraman di Bali, lembang di Toraja, banua dan wanua di Kalimantan, serta negeri di Maluku.

Terbentuknya sebuah desa adat diawali dari berbagai aktivitas kebiasaan yang dilakukan secara turun-temurun oleh sekelompok masyarakat hukum adat. Istilah 'masyarakat hukum adat' biasanya digunakan untuk merujuk pada kelompokkelompok yang merupakan keturunan penduduk asli yang tinggal di suatu wilayah tertentu. Menurut Soerjono Soekanto, masyarakat hukum adat adalah kesatuankesatuan masyarakat yang mempunyai kelengkapan-kelengkapan untuk sanggup berdiri sendiri, yaitu mempunyai kesatuan hukum, kesatuan penguasa, dan kesatuan lingkungan hidup berdasarkan hak bersama atas tanah dan air bagi semua anggotanya. Desa adat telah eksis sebelum Negara Kesatuan Republik Indonesia terbentuk. Sebagai bukti keberadaannya, dalam Pasal 18 Undang-Undang Dasar Negara Republik Indonesia Tahun 1945 (sebelum amandemen) menyebutkan bahwa dalam teritorial Negara Indonesia terdapat lebih kurang 250 'zelfbesturende landschappen' dan 'volksgemeenschappen'. Desa adat tersebut mempunyai susunan asli dan oleh karenanya dapat dianggap sebagai daerah yang bersifat istimewa. Negara Indonesia 
menghormati kedudukan desa adat dan segala peraturan negara yang mengatur mengenai daerah istimewa tersebut akan mengakomodir hak-hak asal-usulnya. Oleh karena itu, keberadaan desa adat wajib tetap diakui dan diberikan jaminan keberlangsungan hidupnya dalam sistem ketatanegaraan Negara Kesatuan Republik Indonesia. $^{5}$

Status dari desa atau kelurahan dapat berubah menjadi desa adat sepanjang masih hidup serta sesuai dengan perkembangan masyarakat dan prinsip Negara Kesatuan Republik Indonesia atas prakarsa masyarakat. Demikian pula status dari desa adat dapat berubah menjadi desa atau kelurahan atas prakarsa masyarakat.

Pada Pasal 26 Undang-Undang Nomor 6 Tahun 2014 tentang Desa diatur bahwa Kepala Desa bertugas menyelenggarakan pemerintahan desa, melaksanakan pembangunan desa, pembinaan kemasyarakatan desa, dan pemberdayaan masyarakat desa. Sangat jelas diamanatkan kepada Kepala Desa untuk menyelenggarakan pembangunan desa, yang tentunya dilaksanakan dengan segala kapasitas yang diberikan kepadanya serta partisipasi masyarakat.

\footnotetext{
5 Andrew Shandy Utama, "Eksistensi Nagari di Sumatera Barat sebagai Desa Adat dalam Sistem Ketatanegaraan di Indonesia Berdasarkan UndangUndang Nomor 6 Tahun 2014 tentang Desa", Jurnal Equitable, Volume 2, Nomor 1, 2017, hlm. 76.
}

Salah satu fenomena saat ini adalah menggeliatnya pembangunan desa sehingga menjadikan desa sebagai pusat pertumbuhan ekonomi. Derasnya aliran dana yang masuk membuka peluang bagi desa untuk terus berkembang. Persoalannya, paradoks pembangunan desa tidak terhindarkan. Bukannya memanfaatkan sumber daya lokal sebagai modal pembangunan, pembangunan yang kasatmata dan padatmodal justru masih menjadi andalan desa meski telah lima tahun Dana Desa digelontorkan. Hingga tahun 2019, pembangunan infrastruktur desa memang dioptimalisasikan menjadi kunci akselerasi pertumbuhan perekonomian. Namun, tanpa diimbangi upaya untuk menjaga keberlangsungan lingkungan hidup dan sosial, efek diskrepansi mulai bermunculan.

Melalui badan usahanya, pemerintah desa merupakan subjek pembangunan desa. Persoalannya, upaya optimalisasi pembangunan desa dalam rangka memperoleh keuntungan secara ekonomi diharapkan mampu menjaga sumber daya alam sesuai dengan arah pembangunan berkelanjutan. Penguatan pembangunan pada komunitas paling dasar ini telah diamanatkan dalam Undang-Undang Nomor 6 Tahun 2014 tentang Desa. Di tengah isu lingkungan dan sosial yang mengemuka, produktivitas pertumbuhan desa sangat ditentukan oleh kualitas sumber 
daya manusia dan kualitas lingkungannya.

Kemampuan sumber daya manusia yang ada di desa harus mampu meningkatkan daya saing kualitas produksi pertanian serta pengelolaan sumber daya alam secara berkelanjutan.

\section{Optimalisasi}

pembangunan

berkelanjutan di desa dilaksanakan demi kelancaran distribusi barang dan jasa dari dan ke desa. Tahap berikutnya yang mungkin dilakukan adalah meningkatkan perekonomian dengan memanfaatkan sumber daya lokal sekaligus menjaga keberlangsungan lingkungan hidup dan sosial sebagai upaya serius guna mempertahankan pertumbuhan pembangunan desa dalam jangka panjang. Hal ini merujuk pada program yang terukur antara pembangunan infrastuktur desa, peningkatan kesadaran hukum masyarakat, serta kepedulian masyarakat terhadap lingkungannya.

Saat ini, kegiatan pembangunan desa sedang menggeliat dan tumbuh karena limpahan anggaran yang ada. Perlu dijaga jangan sampai dampak negatif dari pembangunan menurunkan kualitas kehidupan masyarakat desa. Oleh karena itu, agar desa semakin menarik sebagai lahan investasi dan berwirausaha dalam jangka yang panjang, maka penting untuk meningkatkan tingkat kesadaran hukum masyarakat di desa.
Setidaknya terdapat empat pokok kebijakan penting dalam pembangunan desa ke depan. Pertama, memperjelas visi pembangunan desa. Membangun desa bukan berarti mengubah desa menjadi kota. Visi membangun desa adalah menciptakan kesejahteraan dan standar hidup penduduk desa yang lebih baik dengan tetap menempatkan peran sentral desa sebagai basis ketahanan pangan dan konservasi lingkungan. Hal ini diperkuat oleh fakta bahwa 92,89\% sumber penghasilan utama penduduk desa berasal dari sektor pertanian. Artinya, harus ada sinkronisasi antara pembangunan desa dengan pembangunan pertanian. Selain itu, fungsi desa sebagai konservasi lingkungan juga sangat vital dalam mendukung pembangunan berkelanjutan.

Kedua, perlu menyusun menu kegiatan pembangunan desa yang kreatif. Selama ini sering terjadi pengulangan kegiatan pembangunan yang dibiayai melalui Dana Desa sehingga berpotensi menimbulkan kejenuhan.

Ketiga, mekanisme pengawasan berbasis masyarakat. Dana yang dikelola oleh pemerintah desa sangat besar nilainya. Oleh karena itu, Dana Desa harus diawasi dengan baik agar tidak terjadi penyimpangan yang memberi efek besar bagi desa tersebut. Namun, sebaik apapun sistem pengawasan yang dirancang, tetap tidak mudah untuk mengawasi penggunaan 
Dana Desa. Perlu dibangun mekanisme kebijakan desa yang berdasar pada hukum. Hanya dengan kesadaran hukum dan kepatuhan terhadap hukum maka pengelolaan Dana Desa bisa diselamatkan. Dampaknya tentu pembangunan menjadi tepat sasaran karena tidak ada penyimpangan yang dilakukan. Masih ditemukannya terjadi penyalahgunaan Dana Desa merupakan akibat dari tidak berfungsinya hukum, atau dengan kata lain, kebijakan yang dilaksanakan oleh Kepala Desa tidak lagi berdasarkan hukum yang berlaku.

Terakhir, distribusi kewenangan dari pemerintah pusat ke pemerintah desa sebagai manifestasi dari desentralisasi. Kekuasaan yang tersebar dapat mencegah terjadinya absolutisme di satu sisi dan memungkinkan rakyat untuk mengontrol penggunaan kekuasaan di sisi yang lain. Namun, penyelenggaraan desentralisasi dalam sistem sosial yang masih ditopang oleh jaringan patronase bisa mengancam keberlangsungan negara hukum. Meskipun kekuasaan pemerintah pusat tidak lagi absolut, namun praktik penyalahgunaan kekuasaan oleh kekuasaan-kekuasaan yang sudah terdistribusi masih bisa berlangsung.

Pembentukan peraturan hukum berupa peraturan desa yang demokratis hanya akan terjadi apabila didukung oleh pemerintahan desa yang baik, begitu juga sebaliknya, pemerintahan desa yang baik diperkuat dengan peraturan hukum yang demokratis. Dengan demikian, terdapat hubungan timbal-balik dan saling menunjang antara pemerintahan yang baik dengan peraturan hukum yang demokratis.

Pemerintahan yang baik adalah sekumpulan prinsip dan gagasan tentang: Keabsahan kewenangan dan pertanggungjawaban dari pemerintah; Penghormatan terhadap supremasi hukum dan hak asasi manusia; Berbagai hal lain yang diharapkan oleh rakyat dari pemerintah yang melayani kepentingan khalayak. $^{6}$

Pemerintah yang baik merupakan sebuah kerangka mendasar saat pedagang, petani, buruh, dan kegiatan masyarakat lainnya dapat berjalan dan menghasilkan kesejahteraan secara adil. Pemerintah desa yang baik menjamin hak masyarakat umum untuk mendapatkan pelayanan umum seperti kesehatan, pendidikan, perumahan, dan pelayanan publik lainnya. Tanpa suatu pemerintahan yang baik, sangatlah sulit untuk mewujudkan pelayanan publik dengan kualitas yang baik.

Komunitas masyarakat desa memiliki entitas berupa kebutuhan, tuntutan, dan dukungan terhadap pemerintah sama dengan masyarakat lainnya. Hal ini sudah menjadi tanggung jawab pemerintah desa

6 Solekhan, Penyelenggaraan Pemerintah Desa Berbasis Partisipasi Masyarakat, (Malang: Setara Press, 2014), hlm. 25. 
untuk berupaya melayani dan memenuhi kebutuhan masyarakat dan memuaskan tuntutan masyarakat tersebut. Dalam praktik ketatanegaraan, pemerintah menetapkan berbagai kebijakan untuk mengatur masyarakat melalui peraturan desa agar menumbuhkan pola pemerintahan desa yang baik. ${ }^{7}$

Pemerintah desa memiliki peranan yang signifikan dalam pengelolaan proses hukum dan sosial di masyarakat. Tugas dan kewajiban utama yang diemban oleh pemerintah desa adalah menciptakan kehidupan demokrasi serta memberikan pelayanan kepada masyarakat. Dalam rangka mewujudkan kesejahteraan bagi masyarakatnya, pemerintah desa dituntut untuk melakukan perubahan yang serius, mulai dari kepemimpinan hingga kinerja birokrasi yang berorientasi pada pelayanan yang berkualitas. ${ }^{8}$ Adapun ciri-ciri dari pemerintah yang baik antara lain yaitu: Bersifat menolong; Bergantung pada tata aturan; Bersifat terbuka (transparan); Harus bertangggung jawab; Menghargai dana publik; Bersifat responsif; Menawarkan informasi; Bersifat adil.

Semangat demokratisasi dan otonomi desa menuntut proses pembentukan perundang-undangan terjadi secara demokratis. Adapun karakteristik

7 Azam Awang, Implementasi Pemberdayaan Pemerintah Desa, (Yogyakarta: Pustaka Pelajar, 2010), hlm. 76.

${ }^{8}$ Solekhan, Penyelenggaraan... Op. Cit., hlm. 30. pemerintahan desa yang baik menurut Solekhan adalah:

\section{a. Participation}

Artinya setiap warga negara mempunyai suara dalam pembuatan keputusan, baik secara langsung maupun secara intermediasi dari institusi yang dilegitimasi pemerintah untuk mewakili kepentingannya.

b. Rule of law

Artinya hukum harus dilaksanakan secara adil tanpa pandang bulu, terutama hak asasi manusia, sehingga membuat masyarakat merasa aman dan nyaman.

\section{c. Transparancy}

Artinya terdapat kebebasan arus informasi sehingga masyarakat dapat mengetahui program-program kerja yang telah dijalankan oleh pemerintah desa serta mengawasinya.

\section{d. Equity}

Artinya seluruh masyarakat mempunyai kesempatan yang sama dan mendapat jaminan hidup yang lebih sejahtera.

\section{e. Accountability}

Artinya para pembuat keputusan dalam pemerintahan bertanggung jawab terhadap masyarakat, baik keputusan yang sifatnya internal pemerintahan maupun yang berkaitan dengan kepentingan masyarakat. ${ }^{9}$

\footnotetext{
${ }^{9}$ Ibid., hlm. 28.
} 
Pentingnya

penyelenggaraan

pemerintahan desa yang mengarah pada tata pemerintahan yang baik dalam rangka meningkatkan kinerja pemerintah desa untuk lebih baik lagi. Dalam hal ini, pemerintah desa harus mampu mewujudkan pemerintahan yang baik dengan partisipasi masyarakat yang ikut terlibat dalam penyelenggaraan pemerintahan serta perumusan setiap kepentingan desa agar demokratisasi proses penyelenggaraan pemerintahan desa bisa terbentuk melalui perluasan ruang publik. Dengan demikian, dapat dipahami bahwa pemerintahan desa yang baik adalah sebuah kerangka institusional untuk memperkuat otonomi desa karena secara substantif desentralisasi dan otonomi desa bukan hanya masalah pembagian kewenangan antarlevel pemerintah, melainkan sebagai upaya membawa pemerintah untuk lebih dekat dengan masyarakat. Pemerintah desa yang kuat dan otonom tidak akan bermakna bagi masyarakat tanpa ditopang oleh transparansi, akuntabilitas, responsivitas, dan partisipasi masyarakat.

Selain berharap pada Dana Desa yang dikucurkan oleh pemerintah pusat, kepala desa dan jajaran pemerintahan desa lainnya dapat memanfaatkan program-program Corporate Social Responsibility (CSR) dari perusahaan-perusahaan yang berlokasi di sekitar desa tersebut dalam rangka membangun desa dan mewujudkan kesejahteraan masyarakat. CSR adalah komitmen perusahaan untuk berperan serta dalam pembangunan ekonomi berkelanjutan guna meningkatkan kualitas kehidupan dan lingkungan yang bermanfaat, baik bagi perusahaan sendiri, komunitas setempat, maupun masyarakat pada umumnya. ${ }^{10}$

\section{PENUTUP}

Pelaksanaan tugas Kepala Desa dalam memimpin penyelenggaraan pemerintahan desa dapat dilihat dalam pembuatan rencana kegiatan anggaran dan administrasi desa serta menyusun peraturan desa. Dalam melaksanakan pembangunan desa, Kepala Desa memimpin langsung pembangunan infrastruktur desa seperti pembangunan jalan dan jembatan. Faktor pendukung pelaksanaan tugas Kepala Desa di Kecamatan Trucuk yaitu adanya pengarahan, bimbingan, serta pelatihan bagi Kepala Desa dalam menyusun rancangan peraturan desa untuk mewujudkan percepatan pembangunan desa yang berkelanjutan. Sedangkan, faktor yang menghambat pelaksanaan tugas Kepala Desa di Kecamatan Trucuk yaitu rendahnya partisipasi masyarakat dalam menyikapi program kerja yang dijalankan oleh pemerintah desa serta rendahnya kesadaran

10 Fahrial, Andrew Shandy Utama, dan Sandra Dewi, "Pemanfaatan Corporate Social Responsibility (CSR) terhadap Pembangunan Perekonomian Desa", Jurnal Wawasan Yuridika, Volume 3, Nomor 2, 2019, hlm. 264. 
masyarakat dalam memelihara fasilitas umum yang ada di desa. Pemerintahan desa yang baik adalah sebuah kerangka institusional untuk memperkuat otonomi desa karena secara substantif desentralisasi dan otonomi desa bukan hanya masalah pembagian kewenangan antarlevel pemerintah, melainkan sebagai upaya membawa pemerintah untuk lebih dekat dengan masyarakat. Pemerintah desa yang kuat dan otonom tidak akan bermakna bagi masyarakat tanpa ditopang oleh transparansi, akuntabilitas, responsivitas, dan partisipasi masyarakat.

\section{DAFTAR PUSTAKA}

Abdullah Sulaiman. Metode Penulisan Ilmu Hukum. Jakarta: Universitas Islam Jakarta, 2016.

Abustan. Mozaik Pemikiran Hukum Pasca Reformasi. Makassar: Yayasan AlMuallim, 2007.

Andrew Shandy Utama. "Eksistensi Nagari di Sumatera Barat sebagai Desa Adat dalam Sistem Ketatanegaraan di Indonesia Berdasarkan UndangUndang Nomor 6 Tahun 2014 tentang Desa". Jurnal Equitable, Volume 2, Nomor 1, 2017. Hlm. 75-93.

"Pelaksanaan Tanggung Jawab Sosial dan Lingkungan Perusahaan Berdasarkan UndangUndang Nomor 40 Tahun 2007 untuk Meningkatkan Kesejahteraan Masyarakat Kecamatan Rumbai Pesisir Kota Pekanbaru". Jurnal Cendekia Hukum, Volume IV, Nomor 1, 2018. Hlm. 26-36.

Azam Awang. Implementasi Pemberdayaan Pemerintah Desa. Yogyakarta: Pustaka Pelajar, 2010.
Emile Durkheim dalam Hamzah Fansuri. "Globalisasi; Postmodernisme dan Tantangan Kekinian Sosiologi Indonesia". Jurnal Sosiologi Islam, Volume 2, Nomor 1, 2002.

Fahrial, Andrew Shandy Utama, dan Sandra Dewi. "Pemanfaatan Corporate Social Responsibility (CSR) terhadap Pembangunan Perekonomian Desa”. Jurnal Wawasan Yuridika, Volume 3, Nomor 2, 2019. Hlm. 259-272.

Hasnati dan Andrew Shandy Utama. "Implementation of Corporate Social Responsibility (CSR) by Forestry and Plantation Companies in Pelalawan Regency, Riau Province, Indonesia”. Journal of Law and Political Sciences, Volume 25, Issue 4, 2020. Hlm. 317-332.

Haw Widjaja. Penyelenggaraan Otonomi Daerah di Desa. Jakarta: Rajawali Pers, 2010.

Mohammad Nur Aris. Implementasi Undang-Undang Nomor 6 Tahun 2014 tentang Desa. Jakarta: Tesis Universitas Islam Jakarta, 2019.

Peter Mahmud Marzuki. Penelitian Hukum. Jakarta: Prenada Media, 2011.

Raihan. Lingkungan dan Hukum Lingkungan. Jakarta: Universitas Islam Jakarta, 2012.

Satjipto Rahardjo. Hukum dan Perubahan Sosial. Bandung: Angkasa, 1988.

Soerjono Soekanto. Pengantar Penelitian Hukum. Jakarta: UI Press, 1984.

Solekhan. Penyelenggaraan Pemerintah Desa Berbasis Partisipasi Masyarakat. Malang: Setara Press, 2014.

Sri Mamudji, dkk. Metode Penelitian dan Penulisan Hukum. Jakarta: Badan Penerbit Fakultas Hukum Universitas Indonesia, 2005.

Susi Dwi Harijanti, dkk. Negara Hukum yang Berkeadilan. Bandung: Pusat Studi Kebijakan Negara Fakultas Hukum Universitas Padjadjaran, 2011. 